\title{
Information Transparency Matters in Relation to Consumer Trust in Food Safety
}

\section{Tri Lam}

UQ Business School

The University of Queensland

Queensland, Australia

Email: t.lam@business.uq.edu.au

\section{Jon Heales}

UQ Business School

The University of Queensland

Queensland, Australia

Email: j.heales@business.uq.edu.au

\section{Nicole Hartley}

UQ Business School

The University of Queensland

Queensland, Australia

Email: n.hartley@business.uq.edu.au

\section{Chris Hodkinson}

UQ Business School

The University of Queensland

Queensland, Australia

Email: c.hodkinson@business.uq.edu.au

\section{Abstract}

The purpose of this article is to provide an integrative conceptual model and propositions to assist in understanding whether information transparency matters under the support of traceability systems and online social networking information in relation to consumer trust in food safety. Extant literature forms the foundation for this article. A conceptual model resulting from this proposes that information on food products provided by traceability systems is proposed to stimulate consumers' perceived knowledge of food products. Furthermore, online social networking information advances consumer trust in food product safety. The conceptual model proposes three testable propositions and provides insights into food information that consumers find useful for developing trust in food products.

Keywords Food safety management information systems, consumer trust, online social networking information. 


\section{Introduction}

This article examines the provision of information along the supply chain from inception to consumption and the influence of information on consumer trust in food products. Repeated scandals about food safety have focused public attention on these issues (Marucheck et al. 2011). Food product safety is related to supply chain risk management, and product safety has recently attracted numerous scholarly studies (e.g. De Boeck et al. 2016, Lee and Whang 2005, Marucheck et al. 2011, Pyke and Tang 2010, Tang 2008). Supply chain risk is typical of a disruption or negative result, and in particular, food safety incidents can be triggered by unforeseeable events throughout a global supply chain (Narasimhan and Talluri 2009). On the one hand, considerable risks to a product involve a sufficiency of information in its packaging and labelling (Marucheck et al. 2011). On the other hand, product safety is associated with the process of decreasing the probability of causing infection, harm, or negative consequences to the consumers (Marucheck et al. 2011). Marucheck et al. (2011) suggest that regulated standards, product management, tracking management and relationships management provide comprehensive and optimal solutions to product safety issues.

In fact, food safety scandals are still recurrent on a regular basis. In 1996, mad cow disease was uncovered in Britain through the effects of the disease-ridden meat that resulted in consumers' distrust in food products (Berg 2004). In December 2010, a food scandal across Germany was uncovered when commercial feed containing high concentrations of the toxic chemical dioxin was used in cattle and egg manufacturing processes (Rieger et al. 2016). In the summer of 2014, Shanghai-based Husi Food Co. Ltd was involved in a food-safety scandal using expired meat, and the scandal extended to some American companies including the Starbucks coffee chain and the Burger King food chain because Shanghai Husi Foods was their supplier in China (Xie and Yao 2016). In September 2014, left-over oil, reprocessed oil, and animal feed oil were sold as edible oil in Taiwan, which created a negative impact on Taiwan's food reputation internationally (Ko 2015). Prior to this, between April and July of 2011, a phthalate-tainted food scandal was revealed in Taiwan in which phthalates were deliberately added to several types of food (Tsai et al. 2016). Consequently, food fraud damaged the reputation of food producers (e.g. see Xie and Yao 2016), and created consumer distrust (Spink and Moyer 2011). As a result of these instances, it is debatable whether information retrieved from food traceability systems and online social networks is enough to enhance consumer trust in food products.

Information concerning food quality and safety, and the provision of information relevant to food supply chain are a necessity for food consumers (Lehmann et al. 2011). Chen (2011) found that many consumers were reliant on food product information as it assisted them in food purchase decision making. Therefore, the first research question (RQ1) is: "How food product-related information provided by food traceability systems influences consumer trust in food safety?" When information on food products is provided, communication about the matters of food safety through social media has an influence on product beliefs (Mou and Lin 2014). Based on that, the second research question RQ2 is: "How does online social networking food product-related information intensify consumer trust intentions?" This article continues the progressive research into the factors which influence consumer's trust in food safety and fills a gap in the literature by integrating the extant information systems management and consumer behaviour literatures.

This research project commences by reviewing previous literature on food traceability, consumer trust, food product communication and social media. The application of Social Cognitive Theory (SCT) is then used to integrate perceived knowledge of food products provided by traceability systems with online social networking food product-related information and consumer trust intentions in food safety. Theoretical and practical contributions and implications conclude the paper.

\section{Previous Literature}

In relation to food safety management, information systems refer to data collection, storage, assessment and retrieval (McMeekin et al. 2006). Information systems influence and frame the way for users to make decisions on the safety of food (McMeekin et al. 2006). Specifically, information systems can facilitate Hazard Analysis of Critical Control Points (HACCP), an organised approach that is entailed in carefully documenting all information and actions on food processing and operations (McMeekin et al. 2006). Szymanska (2015) also suggested that electronic information systems were a tool supporting food processing at all stages of formation and supervision. The computer-based tool provides information on farmers and food producers to customers, and shows a product's origin and its composition (Szymanska 2015). Thus food safety management systems (FSMSs) instrument providing food producers with information via reports of authentication and corroboration have been developed (Kirezieva et al. 2013). 
FSMSs refer to the accountability of both the safety of foods and transparency in processing foods (Motarjemi and Mortimore 2005). Food safety management and the control of risks should be approached proactively through efficient FSMSs (Zwietering et al. 2016). Swoffer (2009) indicated that food safety management included raw materials management, usage delineation, and the scrutiny of final products. However, product safety has been perceived as resulting from technical issues such as risks from flawed operational processes that may cause negative consequences for internal and external stakeholders (Lewis 2003) - Table 1 shows stakeholders in food processing and supply chain.

\begin{tabular}{|c|c|c|c|}
\hline Stakeholders & Role & $\begin{array}{l}\text { Information relevant to food } \\
\text { processing and supply chain }\end{array}$ & Supporting literature \\
\hline Food producers & $\begin{array}{l}\text { Ensuring } \\
\text { consumers the } \\
\text { safety of foods }\end{array}$ & $\begin{array}{l}\text { Information of food processing } \\
\text { and supply chain }\end{array}$ & $\begin{array}{l}\text { Motarjemi and } \\
\text { Mortimore (2005), } \\
\text { Govindan (2018) }\end{array}$ \\
\hline $\begin{array}{l}\text { Consumers bodies } \\
\text { or organisations }\end{array}$ & $\begin{array}{l}\text { Providing } \\
\text { guidance }\end{array}$ & $\begin{array}{l}\text { Information about guidance on } \\
\text { food safety }\end{array}$ & $\begin{array}{l}\text { Motarjemi and } \\
\text { Mortimore (2005), } \\
\text { Govindan (2018) }\end{array}$ \\
\hline \multirow[t]{2}{*}{ Governments } & $\begin{array}{l}\text { Formulating, } \\
\text { implementing } \\
\text { and following } \\
\text { policies on food } \\
\text { safety }\end{array}$ & $\begin{array}{l}\text { Information about the occurrence } \\
\text { of any foodborne illness }\end{array}$ & $\begin{array}{l}\text { Motarjemi and } \\
\text { Mortimore (2005), } \\
\text { Govindan (2018) }\end{array}$ \\
\hline & $\begin{array}{l}\text { Communicating } \\
\text { and educating }\end{array}$ & $\begin{array}{l}\text { Information on up-to-date } \\
\text { foodborne issues via mass media } \\
\text { and on the Internet }\end{array}$ & $\begin{array}{l}\text { Motarjemi and } \\
\text { Mortimore (2005), } \\
\text { Govindan (2018) }\end{array}$ \\
\hline $\begin{array}{l}\text { Various middlemen } \\
\text { including } \\
\text { distributors, } \\
\text { wholesalers and } \\
\text { retailers }\end{array}$ & $\begin{array}{l}\text { Coordinating } \\
\text { with } \\
\text { manufacturers }\end{array}$ & $\begin{array}{l}\text { Information about actions such as } \\
\text { distribution and storage }\end{array}$ & $\begin{array}{l}\text { Motarjemi and } \\
\text { Mortimore (2005), } \\
\text { Manders et al. (2016) }\end{array}$ \\
\hline \multirow[t]{2}{*}{ Consumers } & $\begin{array}{l}\text { Consuming food } \\
\text { products }\end{array}$ & $\begin{array}{l}\text { Information concerning blame } \\
\text { and/or experience }\end{array}$ & $\begin{array}{l}\text { Barbarossa et al. } \\
\text { (2016), Manning } \\
\text { (2015) }\end{array}$ \\
\hline & & $\begin{array}{l}\text { Information about discussions on } \\
\text { food safety and risk issues }\end{array}$ & $\begin{array}{l}\text { Mou and Lin (2014), } \\
\text { and Wu (2015) }\end{array}$ \\
\hline
\end{tabular}

Table 1. The extant literature on stakeholders in food processing and supply chain

From a safety perspective, food safety has causal relationships with food supply chains which typically have numerous vulnerabilities, e.g. warehouse and transportation management (Whipple et al. 2009). As a result, the analysis of information concerning FSMSs in a produce chain is likely to provide insights as to quality assurance, and elicit appropriate responses to product safety concerns (Kirezieva et al. 2013). The fundamental component of FSMSs is traceability systems to collect information about activities.

\subsection{Traceability systems and Food Producer Trust}

According to Mattevi and Jones (2016), the main purpose of traceability relates to the safety and quality of products. Wang and Huang (2010) proposed that a traceability system can ameliorate food supply chain performance by monitoring information about potential vulnerability. Traceability or tracing systems can help diagnose the problem and provide information about suppliers, competent authorities and customers (McMeekin et al. 2006). In addition, traceability systems assist in tracking potentially unreliable products in order to take timely preventative and corrective actions (Jansen-Vullers et al. 2003). Therefore a study conducted by Bánáti (2014) recommends that an amalgamation of producer's responsibility, trackability, risk analysis, risk evaluation and risk management is capable of reviving consumers' lost trust but only if it is visible to the consumer.

Due to globalisation, food supply chains necessitate traceability systems to ensure safety and to identify failures in food processing; and many countries have imposed a requirement for traceability systems (King et al. 2017). The integration of traceability systems into information systems assists product 
traceability, and facilitates the development of mobile application for users (Cagliano et al. 2017). For instance, the application of radio-frequency identification (RFID) technology helps track and monitor farm produce and transform the conventional ways of food chain management (Ruiz-Garcia and Lunadei 2011). As a result, tracking and tracing systems throughout the food processing and supply chain are advantageous to stakeholders as they provide on time data collection and thus information transparency (Li et al. 2017). The retention of transparency in a food chain makes consumers feel safe, and aids in restoring consumer trust for food product brands (Chiu 2016).

\subsection{Consumer Trust}

From social theory perspective, the underlying assumption of trust is the belief of a trustor (e.g. food consumers) in a trustee (e.g. food producers) who has competence in satisfying a trustor requirement honestly in a given context (Grandison and Sloman 2003). According to Chen (2008), actors in a food system, monitoring bodies, and truth telling are determinants in consumer trust in food safety. De Jonge et al. (2010) found that optimism and pessimism about food safety were strongly related to trust in food manufacturers. A recent study also shows that perceived country of origin is positively associated with consumers' perception of the reliability and controllability of food incidents, thus lessening consumers' ascription of untrustworthy brands (Barbarossa et al. 2016). Another approach developed by Lassoued and Hobbs (2015) indicates that consumers' perceived brand competence is positively associated with brand trust, i.e. confidence in the safety and quality of food products. A summary of the existing literature on consumer trust in food safety is in Table 2.

\begin{tabular}{llll}
\hline Theory \& Literature & Independent Variable(s) & Dependent Variable(s) & $\begin{array}{l}\text { Supporting } \\
\text { Literature }\end{array}$ \\
\hline $\begin{array}{l}\text { From culture } \\
\text { perspective }\end{array}$ & $\begin{array}{l}\text { 1. } \quad \text { Actors in a food system } \\
\text { 2. Monitoring bodies } \\
\text { 3. Truth telling }\end{array}$ & $\begin{array}{l}\text { Consumers' trust in } \\
\text { food safety }\end{array}$ & Chen (2008) \\
\hline $\begin{array}{l}\text { Consumer confidence } \\
\text { in the safety of food }\end{array}$ & Trust in food manufacturers & $\begin{array}{l}\text { Optimism and } \\
\text { pessimism about food } \\
\text { safety }\end{array}$ & $\begin{array}{l}\text { De Jonge et al. } \\
\text { (2010) }\end{array}$ \\
$\begin{array}{l}\text { The combination of } \\
\text { attribution theory, } \\
\text { country of origin and } \\
\text { national stereotypes } \\
\text { frameworks }\end{array}$ & Perceived country of origin & $\begin{array}{l}\text { Consumers' attributions } \\
\text { of blame }\end{array}$ & $\begin{array}{l}\text { Barbarossa et } \\
\text { al. (2016) }\end{array}$ \\
\hline $\begin{array}{l}\text { Perceived brand } \\
\text { competence }\end{array}$ & $\begin{array}{l}\text { Perceived brand competence } \\
\text { for quality and safety in food }\end{array}$ & Brand trust & $\begin{array}{l}\text { Lassoued and } \\
\text { Hobbs (2015) }\end{array}$ \\
\hline
\end{tabular}

Table 2. The extant literature on consumer trust in food safety

As seen, consumer trust in food safety is scrutinised from different approaches including culture and marketing perspectives. However, the concept of trust is multi-dimensional, and providing truthful information is generally regarded as a prominent characteristic of trust (Frewer et al. 1996).

\subsection{Food Product Communication and Online Social Networking}

Yiannas (2009) recommended the use of multi-media for communicating food safety information such as leaflets, video and websites. A variety of information sources exert a positive and significant influence on consumer trust (Liu et al. 2014). Consumers' trust in food information communicated by public organisations is greater than by private associations (Nocella et al. 2014). For example, Zhang et al. (2016) found that government was the most trustworthy source of information concerning food safety, compared to private certification schemes, e.g. the Safe Quality Food (SQF) Program, a civil-society organisation. In addition, promotional materials related to food safety and health risks increase consumers' awareness of food safety issues (Verçuni et al. 2016).

Social networking sites have provided users with a unique platform for sharing and discussing food safety information (Mou and Lin 2014). Online social networking (OSN) refers to social interactions between individuals about their everyday experiences by providing a venue with appropriate online tools (Merchant 2012). According to Wu's (2015) findings, social media users having positive emotions and concerns about food safety issues tend to search for food safety information and to learn from others. The use of social networking websites for risk consultation pertinent to food safety issues is influenced 
by risk awareness, sentiment, social trust, and social assistance factors (Wu 2015). As such, information and discussions about food products and food safety matters between consumers through social media helps to develop trust intentions in food products.

\section{Conceptual Development}

Food product-related information comes from a wide variety of sources and channels, especially with the support of the Internet and social media. This article aims to develop a conceptual model to predict cognitive perceptions which follows the associations between individual perceived knowledge, social information, and attitude intentions via Social Cognitive Theory (SCT). SCT focuses on cognitive factors (knowledge about a particular fact gained by each individual), environmental elements (facilities and tools designed for a person's eagerness for certain behaviours), and behavioural capabilities (a person's behaviour shaped by their beliefs, attitudes, and perception) that influence each other (Bandura 1986). SCT suggests that personal perceived behaviour (intentions) beliefs (perceive knowledge) and facilities (social information) have interactive associations.

Based on SCT perspective, perceived knowledge of food product provided by food traceability systems, food product-related discussion facilitated by social media, and consumer trust intentions interact each other. A conceptual model is proposed as follows, which focuses on the use of traceability systems and OSN food product-related information that support consumers' trust intentions in food safety. The following subsections will refer to the derivations of the propositions.

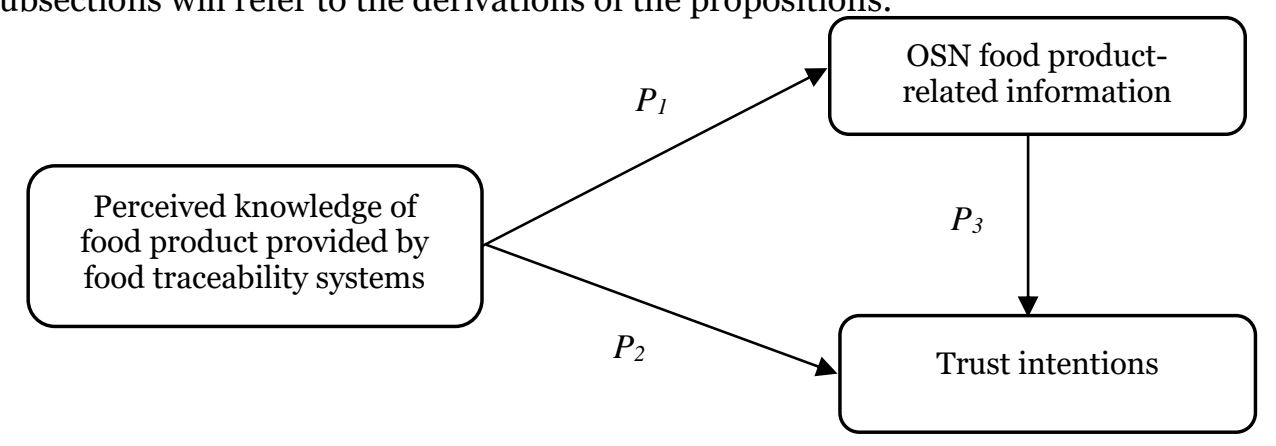

Figure 1. Conceptual model

\subsection{Perceived Knowledge of Food Product Provided by Traceability Systems and OSN Food Product-Related Information}

Derived from SCT, a person's perceive knowledge is in association with their social information need (Bandura 1986). To diminish food contamination and incidents, firms and partners connect each other by accessing reliable and well-timed information concerning supply chain disruptions and outcomes (Premkumar et al. 2005). For instance, the information about date, health benefits, nutrition information, country of origin, and ingredients on food packaging is what can be communicated to consumers with the intention of increasing customer trust (Chan et al. 2012). The above food-related information is managed by FSMSs (Kirezieva et al. 2013). Based in part upon such product information, consumers' knowledge of food products is constructed.

However, to lower perceived risk, consumers require more information to support their food safety perceptions which, in turn, increase their behaviour towards food products (Eiser et al. 2002). With the support of the Internet, communication is easier for consumers who can search for information through online channels (Lee et al. 2000). Statements made by consumers on the Internet and related to a product or corporate brand are considered as electronic word-of-mouth (eWOM) communication (Stauss 2000). Word-of-mouth (WOM) refers to information communications between informal parties as regards assessment of goods and services (Singh 1988; Westbrook 1987). Electronic word-of-mouth communication refers to and includes the following: 'writing', 'liking', 'sharing', 'recommending', 'commenting on', and 'tweeting' brand-related messages on Facebook, Twitter, and other social network media (Wolny and Mueller 2013). These constitute nuanced measures of WOM from a giver's perspective upon goods and services for a particular firm given in the electronic environment (HarrisonWalker 2001). Notably, online communication presents a large volume of information that is disseminated in cyberspace, which has no geographical limitations, and many-to-many online relationships (Wolny and Mueller 2013). These arguments lead to the proposition that: 
P1: A high degree of perceived knowledge of food products provided by traceability systems will be associated with OSN food product-related information.

\subsection{Perceived Knowledge of Food Product Provided by Traceability Systems and Trust Intentions}

The second association proposed by Bandura (1986) is between a person's perceive knowledge and behavioural intensions. Consumer trust in food safety is created when they think food items are safe to eat (Chen 2008). Food is safe when it will not cause sickness or harm to people who consume it, provided that the food is consumed as instructed (Australia New Zealand Food Authority 2016). As mentioned in Table 2, the food supply chain, government involvement, optimism and pessimism, country of origin, and brand competence are pertinent to gaining consumer trust in food products. However, there are still other elements to consider.

Smigic et al. (2015) indicated that there was a need for transparency between various legal authorities and food business operators. Information asymmetry increases consumers' perceived risk, in turn which is likely to use traceability systems (Yoo et al. 2015). Consumers' motives for using traceability systems are reducing perceived risk due to information asymmetry. Producers must retain sufficient records including processing operations, systematic examination, harvesting areas, storage, transportation, and food receipts to corroborate food products are safe by traceability systems (Australia New Zealand Food Authority 2016). To decrease perceptions of risk, the more information provided by food traceability systems to consumers increases their trust in food products (Eiser et al. 2002).

P2: A high degree of perceived knowledge of food products provided by traceability systems will be associated with trust intentions.

\subsection{OSN Food Product-Related Information and Trust Intentions}

The third association based on SCT (Bandura 1986) is the relation between social information facilitated by social media and consumer trust intentions. Trust is aroused by cognition, and evoked by emotion through interpersonal dynamics with the support of information technology (Komiak and Benbasat 2006). Hobbs (2004) showed that consumers preferred to know the safety of food before eating it, otherwise, information asymmetry (e.g. quality attributes known only to producers) can result in market failure. Information asymmetry can frustrate consumers and lead to a loss of confidence in food products among consumers.

The development of the Internet and social network sites, aka online communication, have assisted in reducing information asymmetry and its negative effects by allowing buyers to communicate information on product quality and share their experiences (Izquierdo and Izquierdo 2007). The use of microblogs is associated with generating public awareness of food safety scandals, and they are deemed as a stronger predictor of food safety risk perception compared to other offline media such as television, newspapers and magazines (Mou and Lin 2014). Consumers provide feedback on a product, and in turn, a receiver builds up a personal judicious perception of product or service features (Allsop et al. 2007). Consumers are subjected to a variety of positive and negative information about food to influence their trust in a food product (Scholderer and Frewer 2003). This leads to:

P3: OSN food product-related information will be associated with consumer trust intentions.

\section{Discussion and Conclusion}

Transparency and accountability in the food production chain are desired by consumers so as to know the sources and processes from farm to fork. Incomplete information disclosure of the attributes of food product production is deemed as misspecification, and has the potential to ruin trust between consumers and producers (Mishra et al. 1998). A dearth of reliable information on the market such as dishonest and cheating behaviours could result in a failure in gaining consumer trust (Granovetter 1985), whereas providing trustful information about food products could greatly augment consumer trust (Adler 2001). Traceability systems enable consumers to retrieve information regarding food safety along the processing and supply chain. Traceability assists in tracking any food product through all stages from production, processing to distribution. Traceability also supports mechanisms for tracing backwards and forward at any point in the supply and processing chain (Australia New Zealand Food Authority 2016).

The disclosed information in food traceability systems influences consumer's trust in choosing food products at the point of sale. Additionally, OSN food product-related information bolsters (undermines) consumer trust in a firm's food product. This pragmatic and holistic approach to food chain information 
is important to consumers due to potential information asymmetry between producers and consumers. FSMSs attempt to close this gap. Thus, accurate and readily available information disclosure is a valueadded process for both producers and consumers.

Online feedback mechanisms are corroborated to develop trust in sellers' credibility (Ba and Pavlou 2002). Positive feedback results in both a trustworthy signal and a good feedback profile (Greif 1989; Milgrom et al. 1990). On the other hand, negative feedback leads to not only brand detriment but also financial loss (Lee et al. 2000; Webster and Sundaram 1998). For instance, eBay's Feedback Forum is a channel where buyers provide feedback or reviews about their transactions with sellers. OSN productrelated information is able to affects the user's judgement and facilitate credibility trust.

This research seeks to enhance SCT by examining how technology-supported information influences consumer trust in the context of food safety. Technologies here include traceability systems and social media. The associations between perceived knowledge of food products provided by traceability systems, OSN food product-related information and consumer trust in food safety are articulated. Definitively, the relationships between variables are proposed to be testable.

Food producers can know which factors have positive/negative associations with consumer trust intentions. In addition, food producers can use the constructs and relationships proposed in this model to ameliorate their own FSMSs and OSN communication strategy to increase consumer trust intentions. Finally, there is a possible application to influence consumer purchase behaviour and win consumer loyalty when consumers trust in a product.

The integrated model facilitates cognitive elaboration of consumer trust in food products. The most farreaching implication is the identification of consumers' information need so that some means of communication, such as mobile phone applications, company websites, and social network sites, can be developed to provide appropriate and useful food product information to consumers. Contingent on the food producer's situation, they can work out their own internal and external information systems and decide how their food product information will be disseminated. This will offer valuable assistance in gaining consumer trust. Information on food products is also useful for developing policy on food safety management to prevent foodborne diseases. This might also help reduce societal healthcare costs due to the reduction of food-induced illnesses and industry costs associated with product recalls.

There are several limitations in this article that need consideration. Firstly, other aspects of consumer trust such as consumer practices (Zhang et al. 2016) have not been included in this article. Further research may consider the association between consumers' trust intention and their actual purchasing behaviour. Secondly, this research only considers the effects of OSN food product-related information on consumer trust. Future research could examine the influence of the general mass media on consumer trust in food products. Lastly, this is a conceptual paper that has not proposed any empirics. Hence, the testable model can be further evaluated by using quantitative methods e.g. survey methods.

\section{References}

Adler, P. S. 2001. "Market, hierarchy, and trust: The knowledge economy and the future of capitalism," Organization Science, (12:2), pp. 215-234.

Allsop, D. T., Bassett, B. R., and Hoskins, J. A. 2007. "Word-of-mouth research: Principles and applications," Journal of Advertising Research, (47:4), pp. 398-411 (doi: 10.2501/Soo21849907070419).

Australia New Zealand Food Authority. 2016. A Guide to the Food Safety Standards Safe Food Australia, (3rd editio., Vol. 2), Creative Commons Attribution 3.0 Australia (available at https://www.foodstandards.gov.au/publications/documents/complete_safefood.pdf).

Ba, S., and Pavlou, P. a. 2002. "Evidence of the effect of trust building technology in electronic markets: Price premiums and buyer behavior," MIS Quarterly, (26:3), pp. 243-268 (available at http://www.jstor.org/stable/4132332).

Bánáti, D. 2014. "European perspectives of food safety," Journal of the Science of Food and Agriculture, (94:10), pp. 1941-1946 (doi: 10.1002/jsfa.6611).

Bandura, A. 1986. Social Foundations of Thought and Action: A Social Cognitive Theory Social Foundations of Thought and Action: A Social Cognitive Theory, Prentice-Hall series in social learning theory, Englewood Cliffs, N.J.: Prentice-Hall.

Barbarossa, C., De Pelsmacker, P., Moons, I., and Marcati, A. 2016. "The influence of country-of-origin 
stereotypes on consumer responses to food safety scandals: The case of the horsemeat adulteration," Food Quality and Preference, (53), Elsevier Ltd, pp. 71-83 (doi: 10.1016/j.foodqual.2016.05.015).

Berg, L. 2004. "Trust in food in the age of mad cow disease: A comparative study of consumers' evaluation of food safety in Belgium, Britain and Norway," Appetite, (42:1), pp. 21-32 (doi: 10.1016/So195-6663(03)00112-0).

De Boeck, E., Jacxsens, L., Bollaerts, M., Uyttendaele, M., and Vlerick, P. 2016. "Interplay between food safety climate, food safety management system and microbiological hygiene in farm butcheries and affiliated butcher shops," Food Control, (65), Elsevier Ltd, pp. 78-91 (doi: 10.1016/j.foodcont.2016.01.014).

Cagliano, A. C., De Marco, A., and Rafele, C. 2017. "E-grocery supply chain management enabled by mobile tools," Business Process Management Journal, (23:1), pp. 47-70 (doi: 10.1108/BPMJ-012016-0002).

Chan, C., Kam, B. H., Coulthard, D., and Button, P. 2012. "Consumer Trust of Food Product Information \& Its $\quad$ sources,” (available at https://www.gs1au.org/WorkArea/DownloadAsset.aspx?id=2147484565).

Chen, M. F. 2008. "Consumer trust in food safety-A multidisciplinary approach and empirical evidence from Taiwan," Risk Analysis, (28:6), pp. 1553-1569 (doi: 10.1111/j.1539-6924.2008.01115.x).

Chen, M. F. 2011. "Consumer's trust-in-food-safety typology in Taiwan: Food-related lifestyle matters," Health, Risk \& Society, (13:6), pp. 503-526.

Chiu, H. K. 2016. "Exploring the factors affecting consumer boycott behavior in Taiwan: Food oil incidents and the resulting crisis of brand trust," International Journal of Business and Information, (11:1), pp. 49-66.

Eiser, J. R., Miles, S., and Frewer, L. J. 2002. "Trust, perceived risk, and attitudes toward food technologies," Journal of Applied Social Psychology, (32:11), pp. 2423-2433 (doi: 10.1111/j.15591816.2002.tbo1871.x).

Frewer, L. J., Howard, C., Hedderley, D., and Shepherd, R. 1996. "What determines trust in information about food-related risks? Underlying psychological constructs," Risk Analysis, (16:4), pp. 473-486 (available at http://www.ncbi.nlm.nih.gov/pubmed/8819340).

Govindan, K. 2018. "Sustainable consumption and production in the food supply chain: A conceptual framework," International Journal of Production Economics, (195:March 2017), Elsevier Ltd, pp. 419-431 (doi: 10.1016/j.ijpe.2017.03.003).

Grandison, T., and Sloman, M. 2003. "Trust management tools for Internet applications," in Proceedings of the 1st International Conference on Trust Management, P. Nixon and S. Terzis (eds.), Heraklion, Crete, Greece: Springer-Verlag Berlin Heidelberg NewYork, pp. 91-107.

Granovetter, M. 1985. "Economic action and social structure: The problem of embeddedness," American Journal of Sociology, (91:3), pp. 481-510 (available at http://www.jstor.org/stable/2393756).

Greif, A. 1989. "Reputation and coalitions in Medieval trade: Evidence on the Maghribi traders," Journal of Economic History, (49:4), pp. 857-882.

Harrison-Walker, L. J. 2001. "The measurement of word-of-mouth communication and an investigation of service quality and customer commitment as potential antecedents," Journal of Service Research, (4:1), pp. 60-75 (doi: 10.1177/109467050141006).

Hobbs, J. E. 2004. "Information asymmetry and the role of traceability systems," Agribusiness, (20:4), pp. 397-415 (doi: 10.1002/agr.20020).

Izquierdo, S. S., and Izquierdo, L. R. 2007. "The impact of quality uncertainty without asymmetric information on market efficiency," Journal of Business Research, (60:8), pp. 858-867 (doi: 10.1016/j.jbusres.2007.02.010).

Jansen-Vullers, M. H., Van Dorp, C. A., and Beulens, A. J. M. 2003. "Managing traceability information in manufacture," International Journal of Information Management, (23:5), pp. 395-413 (doi: 10.1016/So268-4012(03)00066-5).

De Jonge, J., van Trijp, H., Renes, R. J., and Frewer, L. J. 2010. "Consumer confidence in the safety of food and newspaper coverage of food safety issues: A longitudinal perspective," Risk Analysis, 
(30:1), pp. 125-142 (doi: 10.1111/j.1539-6924.2009.01320.x).

King, T., Cole, M., Farber, J. M., Eisenbrand, G., Zabaras, D., Fox, E. M., and Hill, J. P. 2017. "Food safety for food security: Relationship between global megatrends and developments in food safety," Trends in Food Science and Technology, (68), Elsevier Ltd, pp. 160-175 (doi: 10.1016/j.tifs.2017.08.014).

Kirezieva, K., Jacxsens, L., Uyttendaele, M., Van Boekel, M. A. J. S., and Luning, P. A. 2013. "Assessment of food safety management systems in the global fresh produce chain," Food Research International, (52:1), Elsevier Ltd, pp. 230-242 (doi: 10.1016/j.foodres.2013.03.023).

Ko, W. H. 2015. "Food suppliers' perceptions and practical implementation of food safety regulations in Taiwan," Journal of Food and Drug Analysis, (23:4), Elsevier Ltd, pp. 778-787 (doi: 10.1016/j.jfda.2015.05.006).

Komiak, S. Y. X., and Benbasat, I. 2006. "The effects of personalization and familiarity on trust and adoption of recommendation agents," MIS Quarterly, (30:4), pp. 941-960 (doi: 10.1002/fut).

Lassoued, R., and Hobbs, J. E. 2015. "Consumer confidence in credence attributes: The role of brand trust," Food Policy, (52), Elsevier Ltd, pp. 99-107 (doi: 10.1016/j.foodpol.2014.12.003).

Lee, H. L., and Whang, S. 2005. "Higher supply chain security with lower cost: Lessons from total quality management," International Journal of Production Economics, (96:3), pp. 289-300 (doi: 10.1016/j.ijpe.2003.06.003).

Lee, J., Kim, J., and Moon, J. Y. 200o. "What makes Internet users visit cyber stores again? Key design factors for customer loyalty," in Proceedings of the SIGCHI conference on Human Factors in Computing Systems, pp. 305-312 (doi: 10.1145/332040.332448).

Lee, Z., Im, I., and Lee, S. J. 200o. "The effect of negative buyer feedback," in Twenty-first International Conference on Information Systems, W. J. Orlikowski, S. Ang, P. Weill, H. Krcmar, and J. I. DeGros (eds.), Brisbane, pp. 286-287.

Lehmann, R. J., Hermansen, J. E., Fritz, M., Brinkmann, D., Trienekens, J., and Schiefer, G. 2011. "Information services for European pork chains - Closing gaps in information infrastructures," Computers and Electronics in Agriculture, (79:2), Elsevier B.V., pp. 125-136 (doi: 10.1016/j.compag.2011.09.002).

Lewis, M. 2003. "Cause, consequence and control: towards a theoretical and practical model of operational risk," Journal of Operations Management, (21:2), pp. 205-224 (doi: 10.1016/So2726963(02)00071-2).

Li, Z., Liu, G., Liu, L., Lai, X., and Xu, G. 2017. "IoT-based tracking and tracing platform for prepackaged food supply chain," Industrial Management \& Data Systems, (117:9), pp. 1906-1916 (doi: 10.1108/IMDS-11-2016-0489).

Liu, R., Pieniak, Z., and Verbeke, W. 2014. "Food-related hazards in China: Consumers' perceptions of risk and trust in information sources," Food Control, (46), Elsevier Ltd, pp. 291-298 (doi: 10.1016/j.foodcont.2014.05.033).

Manders, J. H. M., Caniëls, M. C. J., and Ghijsen, P. W. T. 2016. "Exploring supply chain flexibility in a FMCG food supply chain," Journal of Purchasing and Supply Management, (22:3), Elsevier, pp. 181-195 (doi: 10.1016/j.pursup.2016.06.001).

Manning, L. 2015. "Determining value in the food supply chain," British Food Journal, (117:11), pp. 2649-2663 (doi: 10.1108/BFJ-02-2015-0049).

Marucheck, A., Greis, N., Mena, C., and Cai, L. 2011. "Product safety and security in the global supply chain: Issues, challenges and research opportunities," Journal of Operations Management, (29:78), Elsevier B.V., pp. 707-720 (doi: 10.1016/j.jom.2011.06.007).

Mattevi, M., and Jones, J. A. 2016. "Food supply chain: Are UK SMEs aware of concept, drivers, benefits and barriers, and frameworks of traceability?," British Food Journal, (118:5), pp. 1107-1128 (doi: http://dx.doi.org/10.1108/MRR-09-2015-0216).

McMeekin, T. A., Baranyi, J., Bowman, J., Dalgaard, P., Kirk, M., Ross, T., Schmid, S., and Zwietering, M. H. 2006. "Information systems in food safety management," International Journal of Food Microbiology, (112:3), pp. 181-194 (doi: 10.1016/j.ijfoodmicro.2006.04.048).

Merchant, G. 2012. "Unravelling the social network: Theory and research," Learning, Media and 
Technology, (37:1), pp. 4-19 (doi: 10.1080/17439884.2011.567992).

Milgrom, P., North, D., and Weingast, B. 1990. "The role of institutions in the revival of trade: The medieval Law Merchant," Economics and Politics, (2:I), pp. 1-23 (doi: doi:10.1111/j.14680343.1990.tbooo20.x).

Mishra, D. P., Heide, J. B., and Cort, S. G. 1998. "Information asymmetry and levels of agency relationships," Journal of Marketing Research, (35:3), pp. 277-295 (doi: 10.2307/3152028).

Motarjemi, Y., and Mortimore, S. 2005. "Industry's need and expectations to meet food safety, 5th International Meeting: Noordwijk Food Safety and HACCP Forum 9-10 December 2002," Food Control, (16:6 SPEC. ISS.), pp. 523-529 (doi: 10.1016/j.foodcont.2004.10.014).

Mou, Y., and Lin, C. A. 2014. "Communicating food safety via the social media: The role of knowledge and emotions on risk perception and prevention," Science Communication, (36:5), pp. 593-616 (doi: 10.1177/1075547014549480).

Narasimhan, R., and Talluri, S. 2009. "Perspectives on risk management in supply chains," Journal of Operations Management, (27:2), pp. 114-118 (doi: 10.1016/j.jom.2009.02.001).

Nocella, G., Romano, D., and Stefani, G. 2014. "Consumers' attitudes, trust and willingness to pay for food information," International Journal of Consumer Studies, (38:2), pp. 153-165 (doi: 10.1111/ijcs.12080).

Premkumar, G., Ramamurthy, K., and Saunders, C. S. 2005. "Information processing view of organizations: An exploratory examination of fit in the context of interorganizational relationships," Journal of Management Information Systems, (22:1), pp. 257-294 (doi: 10.1080/07421222.2003.11045841).

Pyke, D., and Tang, C. S. 2010. "How to mitigate product safety risks proactively? Process, challenges and opportunities," International Journal of Logistics Research and Applications, (13:4), pp. 243-256 (doi: 10.1080/13675561003720214 http://www.informaworld.com).

Rieger, J., Kuhlgatz, C., and Anders, S. 2016. "Food scandals, media attention and habit persistence among desensitised meat consumers," Food Policy, (64), Elsevier Ltd, pp. 82-92 (doi: 10.1016/j.foodpol.2016.09.005).

Ruiz-Garcia, L., and Lunadei, L. 2011. "The role of RFID in agriculture: Applications, limitations and challenges," Computers and Electronics in Agriculture, (79:1), Elsevier B.V., pp. 42-50 (doi: 10.1016/j.compag.2011.08.010).

Scholderer, J., and Frewer, L. J. . 2003. "The biotechnology communication paradox: Experimental evidence and the need for a new strategy," Journal of Consumer Policy, (26:2), pp. 125-157.

Singh, J. 1988. "Consumer complaint intentions and behavior: Definitional and taxonomical issues," Journal of Marketing, (52:1), pp. 93-107 (doi: 10.2307/1251688).

Smigic, N., Rajkovic, A., Djekic, I., and Tomic, N. 2015. "Legislation, standards and diagnostics as a backbone of food safety assurance in Serbia," British Food Journal, (117:1), pp. 94-108 (doi: 10.1108/BFJ-08-2013-0228).

Spink, J., and Moyer, D. C. 2011. "Defining the public health threat of food fraud," Journal of Food Science, (76:9), pp. 157-163 (doi: 10.1111/j.1750-3841.2011.02417.x).

Stauss, B. 2000. "Using New Media for Customer Interaction: A Challenge for Relationship Marketing," in Relationship Marketing: Gaining Competitive Advantage Through Customer Satisfaction and Customer Retention, T. Hennig-Thurau and U. Hansen (eds.), (1 st $^{\text {st }}$.), Berlin, Heidelberg: Springer Berlin Heidelberg, pp. 232-253 (doi: 10.1007/978-3-662-09745-8).

Swoffer, K. 2009. "GFSI and the relationship with Codex," in Presentation made at CIES International Food Safety Conference, Barcelona.

Szymanska, K. 2015. "Information system as a tool guaranteeing food safety and controlling food market," in 1oth International Scientific Conference on Economic and Social Development, Miami, pp. 95-102.

Tang, C. S. 2008. "Making products safe: Process and challenges," International Commerce Review, (8:1), pp. 48-55 (doi: 10.1007/s12146-008-0028-2).

Tsai, H. J., Chen, B. H., Wu, C. F., Wang, S. L., Huang, P. C., Tsai, Y. C., Chen, M. L., Ho, C. K., Hsiung, 
C. A., and Wu, M. T. 2016. "Intake of phthalate-tainted foods and microalbuminuria in children: The 2011 Taiwan food scandal," Environment International, (89-90:100), Elsevier B.V., pp. 129137 (doi: 10.1016/j.envint.2016.01.015).

Verçuni, A., Zhllima, E., Imami, D., Bijo, B., Hamiti, X., and Bicoku, Y. 2016. "Analysis of consumer awareness and perceptions about food safety in Tirana , Albania," Albanian Journal of Agricultural Sciences, (15:1), pp. 19-26.

Wang, D., and Huang, D. 2010. "Food supply chain management under conditions of food safety," in 2010 International Conference on Management and Service Science, IEEE, August, pp. 1-4 (doi: 10.1109/ICMSS.2010.5577267).

Webster, C., and Sundaram, D. S. 1998. "Service consumption criticality in failure recovery," Journal of Business Research, (41:2), pp. 153-159.

Westbrook, R. A. 1987. "Product/consumption-based affective responses and postpurchase processes," Journal of Marketing Research, (24:3), pp. 258-270 (doi: 10.2307/3151636).

Whipple, J. M., Voss, M. D., and Closs, D. J. 2009. "Supply chain security practices in the food industry: Do firms operating globally and domestically differ?," International Journal of Physical Distribution \& Logistics Management, (39:7), pp. 574-594 (doi: 10.1108/09600030910996260).

Wolny, J., and Mueller, C. 2013. "Analysis of fashion consumers' motives to engage in electronic word of mouth communication through social media platforms," Journal of Marketing Management, (29:5-6), pp. 562-583 (doi: 10.1080/0267257X.2013.778324).

Wu, C. W. 2015. "Facebook users' intentions in risk communication and food-safety issues," Journal of Business Research, (68:11), Elsevier Inc., pp. 2242-2247 (doi: 10.1016/j.jbusres.2015.06.005).

Xie, Y., and Yao, X. 2016. "A content analysis of the image repair discourses of OSI Group in China's food-safety scandal," Asian Agricultural Research, (8:2), pp. 68-72.

Yiannas, F. 2009. "Communicating Food Safety Effectively," in Food Safety Culture: Creating a Behavior-Based Food Safety Management System, New York: Springer, pp. 49-55 (doi: 10.1007/978-0-387-72867-4).

Yoo, C. W., Parameswaran, S., and Kishore, R. 2015. "Knowing about your food from the farm to the table: Using information systems that reduce information asymmetry and health risks in retail contexts," Information and Management, (52:6), Elsevier B.V., pp. 692-709 (doi: 10.1016/j.im.2015.06.003).

Zhang, L., Xu, Y., Oosterveer, P., and Mol, A. P. J. 2016. "Consumer trust in different food provisioning schemes: Evidence from Beijing, China,” Journal of Cleaner Production, (134), Elsevier Ltd, pp. 269-279 (doi: 10.1016/j.jclepro.2015.09.078).

Zwietering, M. H., Jacxsens, L., Membré, J. M., Nauta, M., and Peterz, M. 2016. "Relevance of microbial finished product testing in food safety management," Food Control, (6o), pp. 31-43 (doi: 10.1016/j.foodcont.2015.07.002). 
Copyright: (C) 2018 Lam, Heales, Hartley \& Hodkinson. This is an open-access article distributed under the terms of the Creative Commons Attribution-NonCommercial 3.0 Australia License, which permits non-commercial use, distribution, and reproduction in any medium, provided the original author and ACIS are credited. 